\title{
Spinal dysraphism with tripedus morphology: A case report
}

\author{
Mohd Monis ${ }^{1}$, Shagufta Wahab ${ }^{2}$, Divyashree Koppal', Aiman Ibbrahim ${ }^{3}$ \\ From ${ }^{1}$ Senior Resident, ${ }^{2}$ Professor, ${ }^{3}$ Junior Resident, Department of Radio Diagnosis, Jawaharlal Nehru Medical College, AMU, Aligarh, \\ Uttar Pradesh, India
}

\begin{abstract}
This is a rare case report of a 5-month-old child with a complex spinal dysraphic state, and an accessory limb (tripedus morphology), accessory genitalia, and anal dimple. The child was brought to the hospital with an accessory limb arising from the back. On clinical examination, an accessory limb arising from the lower back with a partially developed foot with the presence of toes and nails was noted. Spinal MRI was advised which revealed dysraphic features including spina bifida with the low lying and posteriorly tethered cord with diastematomyelia along with a supernumerary appendage attached to the vertebral column having rudimentary bones resembling those of extremities. The presence of an accessory limb with spinal dysraphism is quite a rare anomaly. The condition can be treated by surgical intervention and involves excision of the accessory limb with adequate dural and paraspinal muscle cover.
\end{abstract}

Key words: Accessory limb, Spinal dysraphism, Tripedus

$\mathrm{S}$ pinal dysraphism comprises a group of conditions involving abnormalities of the development of the spine and spinal cord with an incidence ranging from 3.2 to 4.6 per 10,000 births in North America [1]. The presence of a supernumerary (accessory) limb along with spinal dysraphism is an extremely rare anomaly with a limited number of case reports documented so far. Multiple theories were proposed regarding the development of the accessory limb. Females have been reported to be affected more commonly [2]. A number of associated gastrointestinal and urogenital malformations has been described with the entity.

We hereby present an extremely rare case of complex spinal dysraphic state with an accessory limb (tripedus morphology), accessory genitalia, and anal dimple in a 5-month-old male child.

\section{CASE REPORT}

A 5-month-old male child was brought to the pediatric surgery OPD presenting with an accessory limb arising from the back. A detailed clinical history was taken. The antenatal period was uneventful with no history of exposure to teratogenic drugs or ionizing radiation. The child was born at full-term through normal vaginal delivery and had cried immediately after birth. However, after birth, the child was found to have a congenital accessory limb arising from the back. The medical consultation was sought

\section{Access this article online}

Received - 31 October 2021

Initial Review - 16 November 2021

Accepted - 24 November 2021

DOI: $10.32677 /$ ijcr.v7i11.3158 for the same and surgical management was offered. However, due to financial constraints, the parents of the child could not afford the costs, and surgery was postponed for later.

On clinical examination, an accessory limb was noted arising from the lower back with a partially developed foot with the presence of toes and nails. A small soft-tissue protuberance resembling a rudimentary scrotum and depression resembling an anal dimple was seen between the accessory limb and the pelvis of the child (Fig. 1). The growth and development of the child were normal for age and there was no evidence to suggest developmental delay. No other congenital abnormalities were present.

Magnetic resonance imaging (MRI) of the entire spine and brain was advised for detailed evaluation. Spinal MRI (Fig. 2) revealed a low lying cord reaching up to the S2 level and tethered posteriorly. There was the splitting of cord substance at the level of S1/S2 vertebra separated by a midline spur (diastematomyelia). Proximally, syrinx was seen at the level of L4-L5. There was splaying of posterior elements of S1-S3 with a midline defect covered with lipomatous tissue with neural placode-lipoma interface lying at the posterior edge of the spinal canal and nerve roots could be seen protruding through the defect. A large soft-tissue appendage representing an accessory limb was noted arising at the same level. This appendage was skincovered and rudimentary bones resembling those of extremities were visualized within the appendage. The proximal bone of the appendage had the morphology of a vertebral bone (supernumerary

Correspondence to: Dr. Mohd Monis, Senior Resident, Department of Radio Diagnosis, Jawaharlal Nehru Medical College and Hospital, Aligarh, Uttar Pradesh, India. E-mail: mmonis44@gmail.com

(C) 2021 Creative Commons Attribution-NonCommercial 4.0 International License (CC BY-NC-ND 4.0). 
vertebra) and was adhered to the posterior element of S2/S3 and adjoining soft tissues and ligaments. The neural elements (nerve roots) herniating through the spina bifida defect could be seen protruding into the appendage. Brain MRI revealed no significant diagnostic abnormality. No evidence of hydrocephalus or features suggesting Arnold Chiari malformation was seen. No features of corpus callosal dysgenesis or cortical malformations were noted.

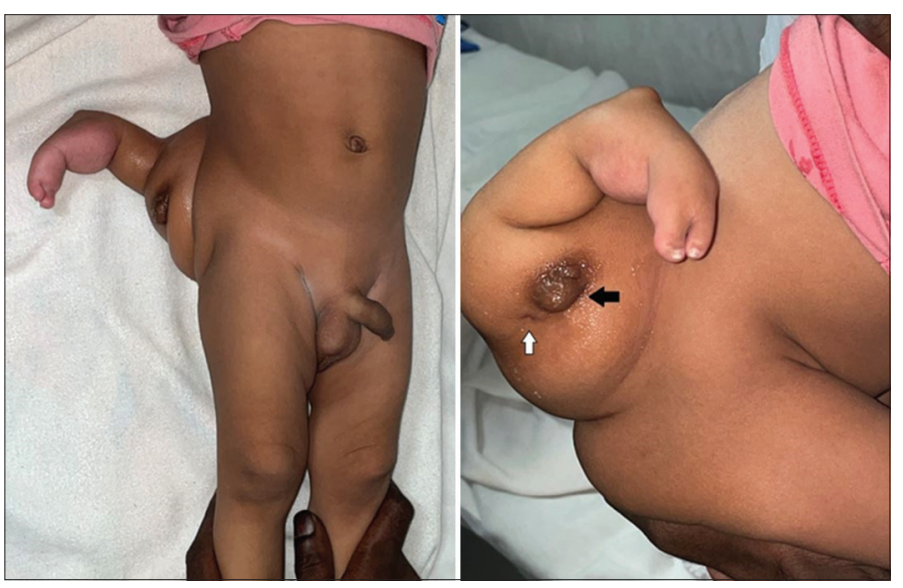

Figure 1: Clinical images of the child with an accessory limb arising from back. Note that the accessory scrotum (black arrow) is visible in between the true limb and the accessory limb along with the accessory anal dimple (white arrow)
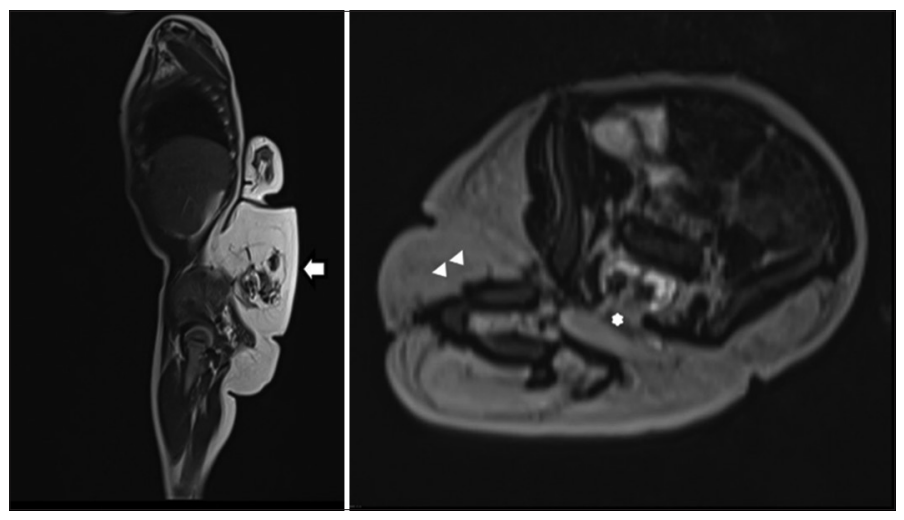

Figure 2: Sagittal and axial T2 MR images show splaying of posterior element of sacral vertebra with midline defect (asterisk) covered with lipomatous tissue and a large soft-tissue appendage (arrow) containing rudimentary bones arising from it S1-S3. Also noted low lying spinal cord seen up to the level of defect with splitting of cord substance separated by a midline spur (diastematomyelia). Supernumerary bone with vertebral morphology (arrowheads) can be seen at the proximal end of accessory limb
Based on the clinical and imaging features, the diagnosis of complex spinal dysraphism with accessory limb was made. Surgical management has been offered to the patient and the prognosis explained. Surgical resection of the accessory limb with adequate dural and soft-tissue cover to the spinal canal is being planned for the management of the patient.

\section{DISCUSSION}

Spinal dysraphism comprises a group of abnormalities of development of the spine and spinal cord. This process of development occurs through three stages of gastrulation, primary neurulation, and secondary neurulation. The various forms of spinal dysraphism developing at different stages of development are described in Table 1 [3].

A presence of an accessory limb with spinal dysraphism is a rare anomaly. Jones and Larkin described the first case operated for accessory limb in 1889 [4]. To date, there have been limited numbers of cases with this diagnosis that has been documented. Various theories have been proposed regarding the development of accessory limb. Gardner (1980) suggested the expansion of the neural tube under cutaneous mesoderm with its subsequent rupture and dispersion of neural fluid into mesodermal tissue, leading to the development of anomalous mesenchymal tissue or an accessory appendage [5]. Krishna et al. (1999) supported this theory for the development of an accessory limb [6]. However, the most widely accepted theory regarding the development of an accessory limb is the fusion hypothesis. According to this theory, there is a failure of development or partial development of one of the embryos of rachipagus conjoint twins. However, some of the parts of the damaged fetus attach to the normally developing embryo through the vertebral column and fail to regress; and continue developing leading to the development of an accessory limb. Solak et al. (2012) supported this fusion hypothesis [7]. Other theories that have been proposed include primary paraaxial mesodermal defect and early splitting of the limb bud [8].

The condition has been more commonly reported in a female child [9]. The previous case reports have also described various other associated abnormalities with this condition. Other reported abnormalities include various gastrointestinal and urogenital malformations such as renal agenesis, accessory bladder exstrophia, accessory genitals, and supernumerary pelvic bones [10]. Krishna et al. described a case of accessory limb

Table 1: List of various forms of spinal dysraphism developing at various stages of development of spine and spinal cord

\begin{tabular}{llll}
\hline Anomalies of gastrulation & Anomalies of primary neurulation & $\begin{array}{l}\text { Combined anomalies of } \\
\text { gastrulation and primary } \\
\text { neurulation }\end{array}$ & $\begin{array}{l}\text { Abnormalities of secondary } \\
\text { neurulation }\end{array}$ \\
\hline Anomalies of notochord formation & Abnormalities of premature dysjunction & $\begin{array}{l}\text { Hemimyelomeningocele } \\
\text { Caudal regression syndrome }\end{array}$ & $\begin{array}{l}\text { Low lying spinal cord } \\
\text { Tethered cord syndrome }\end{array}$ \\
Segmental spinal dysgenesis & Lipomyelocele & $\begin{array}{l}\text { Persisting terminal ventricle } \\
\text { Terminal myelocystocele, }\end{array}$ \\
Anomalies of notochord induction & Spinal lipomas & Abnormalities of non-dysjunction & Intrasacral-anterior sacral \\
Neurenteric cyst & Dorsal dermal sinus & meningocele \\
Diastematomyelia & Myelomeningocele & & \\
& Myeloceles & & \\
\hline
\end{tabular}


associated with spina bifida and accessory genitalia [6]. Accessory genitalia and an accessory anal dimple along with supernumerary vertebra were seen in our case too.

\section{CONCLUSION}

We have described a case of complex spinal dysraphism with an accessory limb (tripedus morphology) attached to the lower vertebral column with accessory genitalia and anal dimple. The treatment of this condition is surgical and involves excision of the accessory limb with adequate dural and soft-tissue cover to the spinal canal and careful post-operative care. Other associated anomalies need to be managed appropriately, sometimes requiring a staged approach.

\section{REFERENCES}

1. Netto JM, Bastos AN, Figueiredo AA, Perez LM. Spinal dysraphism: A neurosurgical review for the urologist. Rev Urol 2019;11:71-81.

2. Ratan SK, Rattan KN, Magu S, Rohilla S, Purwar P, Mathur SK, et al. Thoracolumbar rachipagus parasite. Pediatr Surg Int 2004;20:298-300.
3. Acharya UV, Pendharkar H, Varma DR, Pruthi N, Varadarajan S. Spinal dysraphism illustrated; embroyology revisited. Indian J Radiol Imaging 2017;27:417-26.

4. Jones R, Larkin F. Removal of accessory limb and meningocele from the back of a child, and its anatomy. BMJ 1889;2:310-1.

5. Gardner JW. Hypothesis: Overdistension of the neural tube may cause anomalies of non-neural organs. Teratology 1980;22:229-38.

6. Krishna A, Lal P. Accessory limbs associated with spina bifida-a second look. Pediatr Surg Int 1999;15:248-50.

7. Solak A, Ergun S, Polat I, Şahin N, Genç B. A rare form of heteropagus twinning: Three-armed infant with spinal dysraphism. Case Rep Pediatr 2012;2012:1-4

8. Wasnik A, Shinagare A, Lalchandani U, Gujrathi R, Pai BU. Rudimentary third lower limb in association with spinal dysraphism: Two cases. Indian J Orthop 2007;41:72.

9. Nanni L, Perrelli L, Velardi F. Accessory lower limb in a newborn with multiple malformations. 1994. Eur J Pediatr Surg 1994;4:51-3.

10. Khan RA, Wahab S, Ghani I. Tripedus: A form of rachipagus twinning. Congenit Anom (Kyoto) 2009;49:280-1.

Funding: None; Conflicts of Interest: None Stated.

How to cite this article: Monis M, Wahab S, Koppal D, Ibbrahim A. Spinal dysraphism with tripedus morphology: A case report. Indian J Case Reports. 2021;7(11):509-511. 